\title{
Xanthostemon arenarius (Myrtaceae), a new species from the Cooktown area
}

\author{
Peter G. Wilson
}

\begin{abstract}
Wilson, Peter G. (National Herbarium of New South Wales, Royal Botanic Gardens, Sydney, NSW, Australia 2000) 1993. Xanthostemon arenarius (Myrtaceae), a new species from the Cooktown area. Telopea 5(2): 305-307. A new species of Xanthostemon, apparently restricted to Quaternary dune fields north of Cooktown, is described and its relationships discussed.
\end{abstract}

\section{Introduction}

In my revision of the genus Xanthostemon (Wilson 1990), there was a mention of specimens that resembled $X$. youngii in leaf morphology and came from a similar habitat. However, it was also stated that there were unconfirmed reports suggesting that the flowers were yellow rather than red. Recent collections have confirmed that the flowers are yellow and, further, show that the species is also distinct from X. chrysanthus.

\section{Xanthostemon arenarius Peter G. Wilson, sp. nov.}

Arbor media, cortice duro, laminato. Folia juniora adultaque spirales, laminis plerumque $5-9 \mathrm{~cm}$ longis et $2-4.5 \mathrm{~cm}$ latis, coriaceis, subter parce puberulis, apicibus obtusis vel rotundatis. Flores flavi, petalis plusminusve cucculatis, $4.5-6.5 \mathrm{~mm}$ longis, hypanthio cupulato puberulo, staminibus uniseriatis, ovario glabro, placenta horizontali. Capsula subglobosa, 1.0-1.4 cm diametro, 3-4-locularis; semina non alata.

TYPE: QuEENSLAND: Cook: $9.2 \mathrm{~km}$ from Elim on the road to Hopevale, J.R. Clarkson 8716 \& V.J. Neldner, 23 May 1990; holo NSW; iso MBA, QRS, K.

Tree mostly 5-6 m high, occasionally an emergent to $20 \mathrm{~m}$; bark hard and platy, grey to grey-brown; shoots and twigs puberulent. Leaves spirally arranged in both juvenile and adult plants; petiole $0.8-1.9 \mathrm{~cm}$ long; lamina obovate to elliptical, length:breadth ratio 1.6-2.9:1, (4.2-)5.3-8.2(-9.6) cm long, $2.0-4.5 \mathrm{~cm}$ wide, coriaceous with prominent venation, apex mostly obtuse to rounded, puberulent when young, glabrescent or hairs persistent on petiole and undersurface of midrib; oil glands numerous, small, usually inconspicuous in dried leaves. Inflorescences crowded at apex of seasonal growth unit, subtended by very reduced foliage leaves, axillary, the apical bud not always growing on; unit inflorescences monads, triads, metaxytriads and possibly botryoids; peduncle 4-8 $\mathrm{mm}$ long. Hypanthium cup-shaped, 5.5-6 $\mathrm{mm}$ in diameter, exceeding the summit of the ovary, puberulent. Petals 5, yellow, \pm hooded, obovate, 4.5-6.5 mm long, $3-5.5 \mathrm{~mm}$ wide, puberulent on the outer surface, margins ciliate. Sepals 5, unequal, the larger somewhat petaloid, $1.5-3 \mathrm{~mm}$ long, deltoid to oblong, puberulent on the outer surface. Stamens c. 20, in a single series around the rim of the hypanthium, filaments 10-19 mm long, anthers 1.1-1.5 mm long, connective broad with one large gland at the apex and up to two other, smaller glands. Ovary halfinferior, (2-)3-4-locular, glabrous. Style 18-22 mm long; stigma narrower than the style, flat. Placentas rod-like, terete, horizontal; ovules c. 20 per loculus, arranged in 
an uninterrupted whorl at the apex. Fruit broad-ovoid, 1.0-1.4 cm in diameter, 0.8-1.2 $\mathrm{cm}$ high; hypanthium initially partly enclosing the base of the fruit but splitting and becoming \pm flattened under the capsule. Seeds not winged, $4.25-6.0 \mathrm{~mm}$ long. Figure 1.

Distribution: Only known from the Cook District of Queensland, from a restricted area on the coast north of Cooktown, between $15^{\circ} 00^{\prime}$ and $15^{\circ} 30^{\prime} \mathrm{S}$, in the Cape Bedford - Cape Flattery area. Figure 2.

HABITAT: White or grey sandy soils; in closed forest on Quaternary dune systems dominated by Asteromyrtus angustifolia or Araucaria at an altitude of $20-80 \mathrm{~m}$.

CONSERVATION STATUS: $2 R$. Occurs entirely within the Hopevale Aboriginal Reserve where it is locally common. There is some sand mining within this area but this is not considered a threat to the long-term future of the plant (J. Clarkson, pers. comm.).

Notes: The epithet is derived from the Latin arenarius, of sand, growing on sand.

$X$. arenarius shows greatest similarity to $X$. chrysanthus which it resembles in having spirally arranged leaves, yellow flowers and horizontal placentas but it differs in having shorter leaves with longer, more slender petioles and in having puberulent flowers with smaller petals with inconspicuous oil glands. The species are also very different in their habitat, $X$. chrysanthus being found most commonly in gallery rainforest. The species may be distinguished as follows:

Petiole mostly 4-7 mm long, 1.5-2 mm diam.; lamina usually $>10 \mathrm{~cm}$ long, elliptical to oblanceolate; flowers \pm glabrous, petals $7-9 \mathrm{~mm}$ long with conspicuous oil glands

X. chrysanthus

Petiole over $8 \mathrm{~mm}$ long, 1-1.5 mm diam.; lamina $<10 \mathrm{~cm}$ long, obovate to elliptical; flowers puberulent, petals $4.5-6.5 \mathrm{~mm}$ long with inconspicuous oil glands

X. arenarius

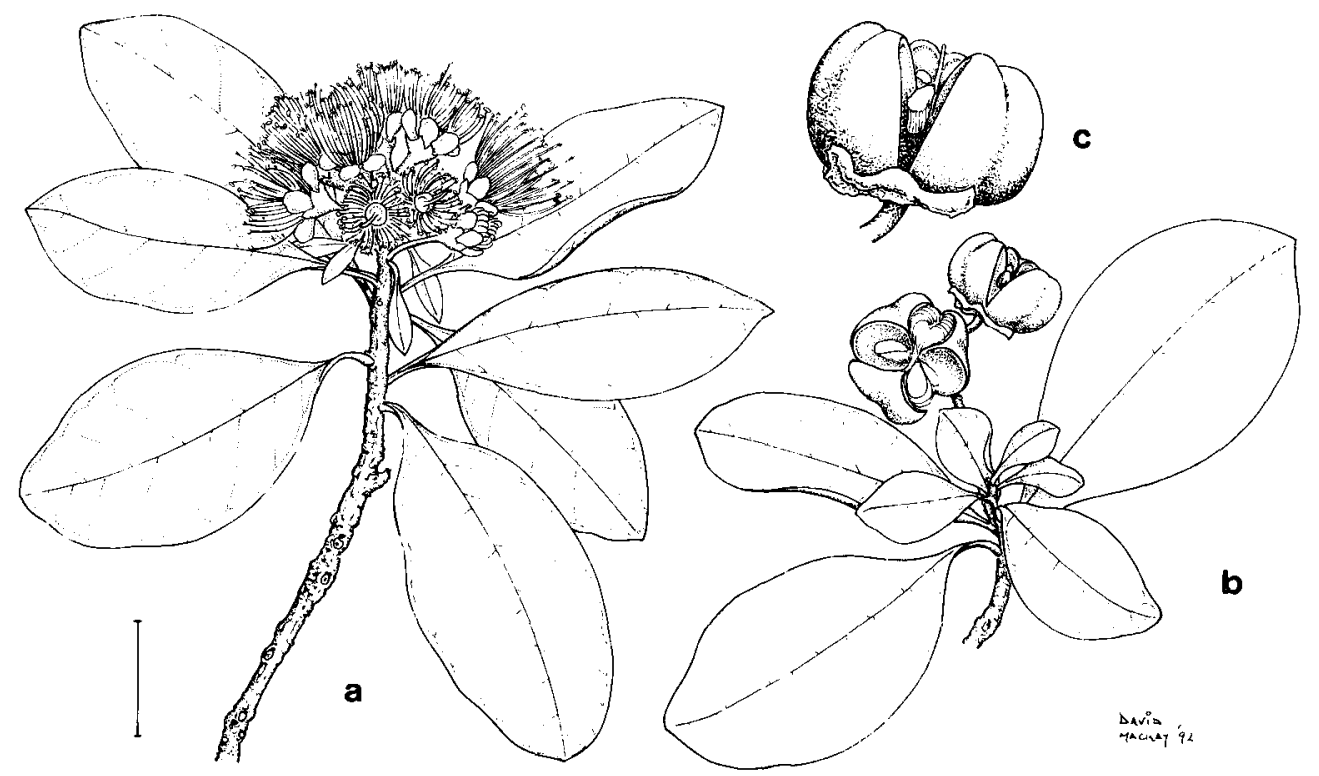

Figure 1. Xanthostemon arenarius. a, leafy branchlet with flowers, scale bar $20 \mathrm{~mm}$; , leafy branchlet with fruit, scale bar $20 \mathrm{~mm}$; c, detail of fruit, scale bar $10 \mathrm{~mm}$. (a from Clarkson 8716; b \& c from Clarkson 8743). 


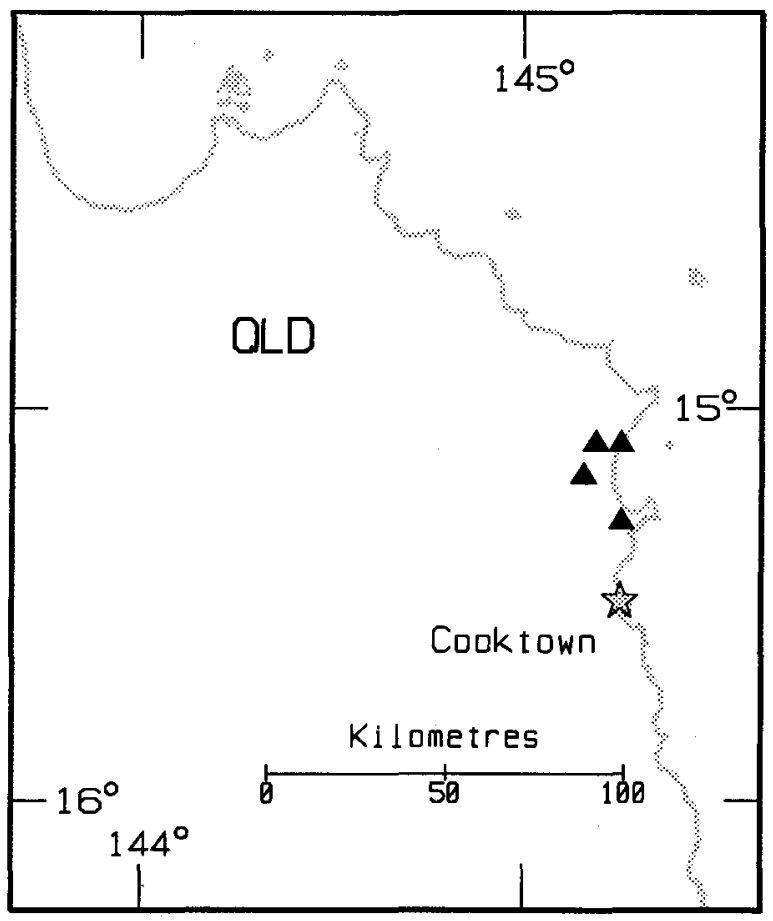

Figure 2. Distribution of Xanthostemon arenarius.

OTHER SPECIMENS EXAMINED: QUEFNSLAND: Cook: c. $9.5 \mathrm{~km}$ east of the Hopevale to Starcke road on the track to the mouth of the McIvor River, Clarkson 7292, 29 July 1987 (NSW); c. 3 km from the Hopevale to Starcke road on the road to the rehabilitation centre on the McIvor River, Clarkson 8743 \& Neldner, 25 May 1990 (NSW); Aboriginal Reserve 1 between McIvor R. \& Cape Flattery, Hyland 6509, 21 Nov 1972 (QRS); Hyland 2759 RFK, 22 Nov 1972 (QRS, UNSW).

\section{Acknowledgements}

I am most grateful to John Clarkson for his efforts to collect flowering material of this species and for information relating to its conservation status. My thanks also to David Mackay for the excellent illustration.

\section{Reference}

Wilson, P.G. (1990) A revision of the genus Xanthostemon (Myrtaceae) in Australia. Telopea 3: $451-476$.

Manuscript received 30 June 1992

Manuscript accepted 1 December 1992 